\title{
Sosialisasi dan Pelatihan Pengolahan Sampah Organik Rumah Tangga Menjadi Kompos dengan Teknologi Komposter terhadap Masyarakat RT 01 RW 03 Desa Rejosari Kecamatan Tenayan Raya
}

\author{
M.Reza*1, Shinta Elystia², Aryo Sasmita3 ${ }^{3}$ Gunadi Priyambada4, David Andrio5, \\ Jecky Asmura 6
}

\author{
1,2,3,4,5,6 Teknik Lingkungan, Fakultas Teknik, Universitas Riau, Indonesia \\ *e-mail: zha6290@gmail.com ${ }^{1}$, shinta.elystia@lecturer.unri.ac.id ${ }^{2}$ aryosasmita@lecturer.unri.ac.id $^{3}$ \\ gunadipriyambada@lecturer.unri.ac.id ${ }^{3}$, davidandrio@lecturer.unri.ac.id $^{4}$, \\ jeckyasmura@lecturer.unri.ac.id ${ }^{5}$
}

\begin{abstract}
Abstrak
Desa Rejosari memiliki 17 RW 70 RT dengan 4.888 KK. Potensi sampah yang dihasilkan cukup tinggi. Hal ini terlihat dari tumpukan sampah di beberapa tempat yang ada di lingkungan RT 01 RW 03. Hasil observasi tim pengabdian diketahui tidak adanya sistem pengangkutan sampah dari pemerintah, sehingga masyarakat membakar sampah, membuang sampah di lahan kosong, dan dibuang ke sungai. Munculnya masalah yaitu sampah-sampah yang dapat mencemari lingkungan dan menyebabkan timbulnya wabah penyakit. Padahal sampah-sampah tersebut dapat dimanfaatkan untuk menjadi produk-produk yang bermanfaat seperti menjadi pupuk kompos serta barang kerajinan yang bernilai ekonomi. Melihat kondisi ini tim pengabdian dengan berkoordinasi dengan pejabat setempat (Ketua RT 01) menyusun jadwal pelaksanaan kegiatan Sosialisasi \& Pelatihan Pengolahan Sampah Organik Rumah Tangga menjadi Kompos dengan Teknologi komposter. Kegiatan sosialisasi dan pelatihan dilakukan dengan metode penyuluhan dan demonstrasi pembuatan pupuk kompos oleh tim dan warga masyarakat sekitar. Kegiatan ini dihadiri narasumber berasal dari dosen Teknik Lingkungan Universitas Riau dan warga masyarakat di wilayah RT 01 RW 03 Desa Rejosari Kecamatan Tenayan Raya. Manfaat yang diperoleh peserta dari kegiatan PKM ini antara lain warga masyarakat dapat mengolah sampah organik menjadi pupuk kompos dengan teknologi komposter serta meningkatnya pengetahuan dalam pengelolaan dan pengolahan sampah sehingga lingkungan menjadi lebih bersih dan nyaman serta bisa meningkatkan perekonomian.
\end{abstract}

Kata kunci: Komposter, Pupuk Kompos, Sampah Organic Rumah Tangga

Abstract
Rejosari Village has 17 RW 70 RT with 4,888 families. The potential for waste generated is quite high. This can be seen from the piles of garbage in several places in the neighborhood of RT 01 RW03. The observation results of the community service team found that there were no household waste disposal sites and no garbage transportation system, so people threw their garbage on empty land or into rivers. The emergence of problems, namely waste that can pollute the environment and cause disease outbreaks. In fact, the waste can be used to make useful products such as compost and handicrafts with economic value. Seeing this condition, the community service team in coordination with local officials (Head of RT 01) Prepared a schedule for the implementation of the Socialization \& Training of Household Organic Waste Processing into Compost with Composting Technology. The socialization and training activities were carried out using counseling methods and demonstrations of making compost by the team and local residents. This activity was attended by trainer from lecturer of Environmental Engineering University of Riau and community members in the area of RT 01 RW 03, Rejosari Village, Tenayan Raya District. The benefits that participants god from this PKM activity include community members being able to process organic waste into compost using composter technology and increasing knowledge in waste management and processing so that the environment becomes cleaner and more comfortable and can improve the economy.

Keywords: Composter, Compost, Household Organic Waste

\section{PENDAHULUAN}

Sampah adalah segala buangan yang timbul akibat aktivitas manusia dan hewan, biasanya berupa padatan yang dianggap tidak berguna atau tidak diiinginkan lagi (Tchobanoglous et al., 
2002). Selama ini sampah menjadi permasalahan yang sangat kompleks dan sangat luas dalam kota. Masalah sampah secara umum antara lain adanya peningkatan volume timbulan sampah tetapi tidak diringi dengan dana pengelolaan, sistem manajemen, serta kesadaran masyarakat akan pengelolaan sampah (Damanhuri, 2010).

Kelurahan Rejosari terletak di wilayah timur Kecamatan Tenayan Raya Kota Pekanbaru. Luas wilayah Kelurahan Rejosari adalah 556 Kilometer Persegi. Penduduk Kelurahan Rejosari sebagian besar di dominasi oleh sektor perdagangan dan jasa $(44,34 \%)$, Peternak $(8,98 \%)$, Pertanian (6,31\%), Kerajinan dan Industri Kecil (4,94\%), Perkebunan (4,45\%), dan sektor lainnya (30,98\%). Desa Rejosari memiliki 17 RW 70 RT dengan 4.888 KK. Potensi sampah yang dihasilkan cukup tinggi. Hasil observasi tim pengabdian diketahui beberapa permasalahan yang teridentifikasi di lokasi pengabdian sehingga dirasa penting untuk segera dilakukan pelatihan, antara lain: peningkatan volume sampah seiring meningkatnya jumlah penduduk, pola konsumsi masyarakat yang mempengaruhi peningkatan volume sampah, pengelolaan sampah masih kurang, sampah di bakar, di buang ke lahan kosong dan sungai, sehingga menimbulkan berbagai permasalahan lingkungan. Peran masyarakat dalam pengelolaan sampah kebanyakan masih sebatas membuang sampah di tempat yang seharusnya atau belum pada pengolahan sampah yang memberikan manfaat kembali bagi masyarakat. Masih rendahnya pengetahuan masyarakat tentang pengelolaan sampah rumah tangga. Masyarakat belum diberdayakan dalam pengelolaan sampah rumah tangga dengan metode Komposting menggunakan komposter. Pupuk kompos yang dibuat dari bahan sampah organik juga bisa digunakan untuk perawatan tanaman dalam sistem pertanian organik. Dengan mengolah menjadi kompos akan membuat tanah menjadi subur karena kandungan unsur hara bertambah (Suryati, 2008). Menurut Faatih (2012), pengomposan merupakan salah satu proses pengolahan limbah organik menjadi material baru seperti halnya humus.

Melihat kondisi ini tim pengabdian dengan berkoordinasi dengan pejabat setempat (Ketua RT 01) menyusun jadwal pelaksanaan kegiatan Sosialisasi \& Pelatihan Pengolahan Sampah Organik Rumah Tangga menjadi Kompos dengan Teknologi Komposter. Kegiatan pengabdian pada masyarakat bagi dosen-dosen di Program Studi Teknik Lingkungan yang saat ini diperlukan oleh warga adalah pengelolaan dan pengolahan sampah organik menjadi kompos dengan metode sederhana. Dari masalah-masalah tersebut dapat dirumuskan masalah sebagai berikut:

a. Bagaimana meningkatkan pengetahuan masyarakat tentang pengelolaan sampah rumah tangga dengan metode komposting?

b. Bagaimana memberdayakan masyarakat dalam pengelolaan sampah rumah tangga dengan metode komposting?

Oleh karena itu dipandang perlu bagi dosen-dosen Program Studi Teknik Lingkungan untuk melakukan sosialisasi dan pelatihan bagi masyarakat lingkungan RT 01 RW 03 Desa Rejosari Kec. Tenayan Raya Kota Pekanbaru tentang pengelolaan dan pengolahan sampah organik menjadi kompos dengan cara sederhana yang mudah dipahami dan diterapkan oleh masyarakat. Sehingga, meningkatkan nilai manfaat sampah menjadi bahan yang lebih berguna dan mengurangi pencemaran lingkungan.

\section{METODE}

Kegiatan Pengabdian ini dimulai dengan identifikasi permasalahan yang timbul di masyarakat RT 01 RW 03 Desa Rejosari, Kecamatan Tenayan Raya Kota Pekanbaru. Kemudian dilanjutkan dengan penyusunan rancangan tahapan kegiatan. Adapun kegiatan pengabdian kepada masyarakat terdiri atas beberapa tahap yaitu:

1) Survei ke lokasi mitra wilayah RT 01 RW 003 Desa Rejosari untuk menggali lebih lanjut permasalahan dan kebutuhan mitra.

2) Merencanakan kegiatan pengabdian pada masyarakat dalam upaya untuk memperbaiki masalah terkait pengelolaan sampah organic sesuai kebutuhan mitra.

3) Pembuatan Komposter oleh tim pengabdian masyarakat prodi Teknik Lingkungan UNRI. 


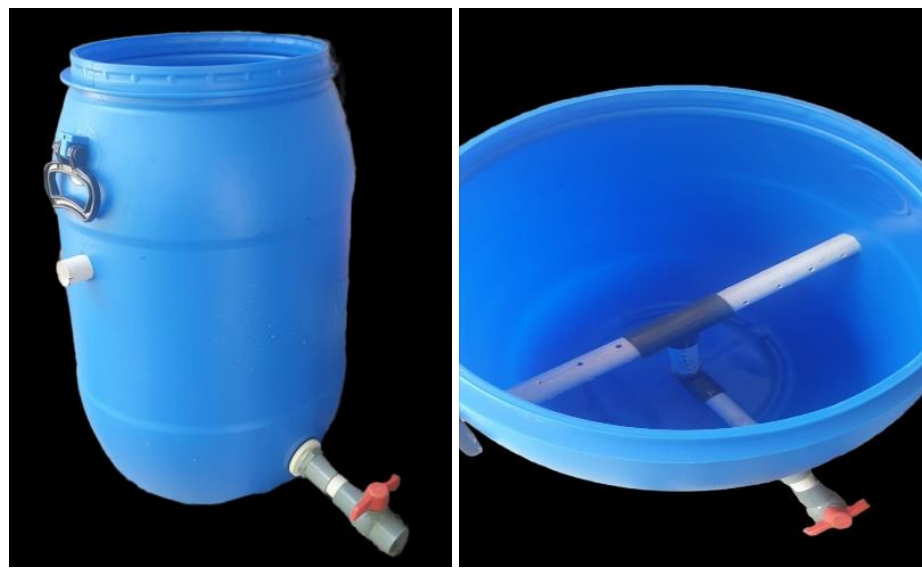

Gambar 1. Komposter Sampah Organik Rumah Tangga

Bahan-bahan yang digunakan untuk pembuatan komposter terdiri dari: Drum volume 60L, Pipa PVC $1 \frac{1}{2}$ inch (6 m) dan $1 \frac{1}{4} 4$ inch (6m), Bor, Gerinda, Pipa alumunium $1 / 4$ inch dan lem pipa.

4) Melaksanakan kegiatan pengabdian pada masyarakat sesuai jadwal yang disepakati antara tim dan mitra.

Metode kegiatan pengabdian yang digunakan, antara lain:

a. Ceramah Metode ceramah dipilih untuk menyampaikan konsep tentang lingkungan hidup, klasifikasi sampah, peran serta perempuan dalam pengelolaan lingkungan hidup, serta pengelolaan sampah rumah tangga dengan metode komposting. Apabila peserta pelatihan tidak jelas dengan materi yang disampaikan oleh nara sumber dapat memberikan pertanyaan secara langsung atau tidak harus menunggu sesi tanya jawab.

b. Demonstrasi Metode demonstrasi dipilih untuk menunjukkan suatu proses kerja sehingga dapat memberikan kemudahan bagi peserta pelatihan. Demonstrasi dilakukan oleh tim pengabdi sebagai nara sumber dengan harapan peserta pelatihan dapat melaksanakan simulasi secara sempurna

c. Pemberian unit komposter, EM4, dan Modul Teknologi Lingkungan Tepat Guna Pengolahan Sampah menjadi Kompos (Komposting).

5) Melakukan pengamatan dan observasi untuk mengetahui dampak/hasil yang tampak saat pelaksanaan kegiatan.

Pengabdian kepada masyarakat ini dilaksanakan di wilayah RT 01 RW 03 Desa Rejosari, Kecamatan Tenayan Raya Kota pekanbaru. Kegiatan ini akan dilaksanakan pada tanggal 3 Oktober 2021. Adapun luaran yang diharapkan dari kegiatan ini adalah:

1) Warga masyarakat wilayah RT 01 RW 03 Desa Rejosari, mengetahui perbedaan sampah organik dan anorganik serta mampu memilahnya.

2) Peningkatan daya guna sampah. Sampah organik dari sisa-sisa makanan dan sayur yang awalnya tidak berdaya guna (dibuang), menjadi memiliki nilai tambah setelah dijadikan pupuk kompos.

3) Terciptanya lingkungan yang lebih bersih dan sehat di wilayah RT 01 RW 03 Desa Rejosari, Kecamatan Tenayan Raya Kota pekanbaru.

\section{HASIL DAN PEMBAHASAN}

\subsection{Survei Pendahuluan dan Persiapan Materi Kegiatan}

Survei pendahuluan telah dilaksanakan pada Senin tanggal 20 September 2021 di RT 01 RW03 Desa Rejosari. Kunjungan tersebut bertujuan untuk mengurus perizinan di kelurahan tersebut. Selain itu, pada kunjungan tersebut diperoleh kesepakatan dengan Ketua RT, bahwa akan dilaksanakan kegiatan pengabdian kepada masyarakat sesuai dengan topik, serta penjadwalan tahap kegiatan. Secara garis besar juga dijelaskan beberapa tahapan yang akan 
dilaksanakan, yakni selain sosialisasi dan pelatihan pengolahan sampah organik rumah tangga menjadi kompos kepada peserta kegiatan.

\subsection{Sosialisasi dan Pelatihan}

Kegiatan pengabdian masyarakat terhadap warga RT 01 RW03 Desa Rejosari dengan topik Sosialisasi \& Pelatihan Pengolahan Sampah Organik Rumah Tangga menjadi Kompos dengan Teknologi Komposter telah dilaksanakan pada tanggal 3 Oktober 2021 pada pukul 09.00 - 12.00. Kegiatan pengabdian di hadiri oleh 10 orang warga. Peserta yang hadir setengah dari undangan yang diberikan, dikarenakan masih adanya rasa takut warga akan penyebaran virus covid 19.

Kegiatan pengabdian dilaksanakan dalam bentuk sosialisasi dan demonstrasi pengolahan sampah organik menjadi kompos dengan komposter. Penjelaskan materi yaitu pemilahan sampah, tata cara pengolahan kompos dengan menggunakan komposter, materi dilengkapi dengan modul pengolahan sampah menggunakan komposter sehingga peserta dapat menerima dan memahami materi dengan baik. Setelah disampaikan materi mengenai sampah, teknik pemilahan dan pengolahan sampah dilanjutkan dengan demonstrasi pembuatan kompos dari sampah organik dengan komposter. Kegiatan ini dimulai dengan Teknik membuat komposter sederhana rumahan, bahan-bahan yang diperlukan adalah:

1) Tempat penampungan sampah organik beserta tutupnya, perkirakan ukuran sesuai volume sampah organik yang dihasilkan pada rumah kita. Contoh: ember atau tong plastik (barangbarang ini mudah kita dapat). Tutup kita perlukan, agar sampah yang ditampung dalam wadah tersebut tidak didatangi lalat. Buat lubang kecil-kecil pada wadah yang kita pilih, agar oksigen bisa masuk, dan pastikan juga lubang-lubang kecil di bagian bawah wadah untuk mengeluarkan lindi (cairan sisa pembusukan).

2) Cairan EM4, sebagai makanan bakteri untuk mempercepat proses penguraian sampah (bisa dibeli di toko-toko pertanian).

3) Sedikit air untuk mengencerkan larutan EM4.

4) Gunting atau pisau untuk merajang sampah, disini ukuran sampah organik sengaja di potongpotong agar proses pembusukan berlangsung cepat.

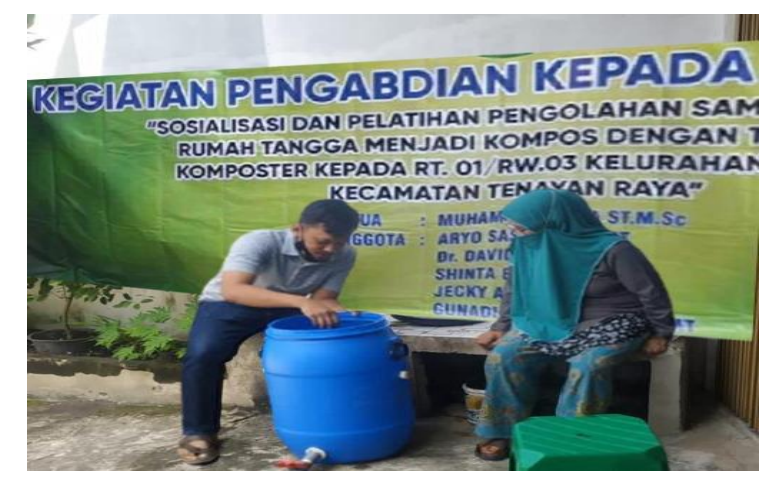

Gambar 2. Praktek Teknik Pembuatan Komposter Rumah Tangga

Pada sosialisasi dan pelatihan ini diberikan kesempatan yang seluas-luasnya kepada peserta untuk bertanya tentang topik yang dipaparkan ataupun sampah secara umum. Ceramah dan diskusi berjalan cukup lancar. Beberapa peserta menanyakan tentang bahan baku kompos. Ketika diskusi berlangsung, ada peserta sudah pernah mencoba membuat kompos, namun hasil kompos tidak terlalu baik, warna cokelat dan sedikit berbau dan memakan waktu yang cukup lama sekitar 1 bulan. Bahan baku dan proses pembuatan kompos yang diikuti oleh masyarakat tersebut hampir sama dengan yang dijelaskan namun tidak menggunakan tambahan EM4. Pada diskusi ini dianjurkan menggunakan mikroorganisme yang selektif untuk kompos yang disebut efective microorganism dan mudah dibeli di toko-toko pertanian. Aktivator EM4 merupakan bahan yang mengandung beberapa mikroorganisme yang sangat bermanfaat dalam proses pengomposan. Manfaat EM4 sendiri dapat meningkatkan fermentasi limbah dan sampah organih, 
meningkatkan ketersediaan unsur hara untuk tanaman, serta menekan aktivitas serangga, hama dan mikroorganisme pathogen (Djuarnani, 201).

Pada peragaan pembuatan kompos, dijelaskan pula proses pencacahan bahan baku seperti daun-daunan dan batang pohon-pohonan. Ukuran bahan yang relatif kecil akan memudahkan proses pengkomposan oleh mikroorganisme dan waktu pengkomposan menjadi lebih singkat. Ciri-ciri kompos yang sudah jadi adalah warna berubah menjadi hitam dan remuk. Agar kompos yang diaplikasikan ke tanaman bentuknya seragam, setelah kompos di panen, dilakukan proses pengayakan.

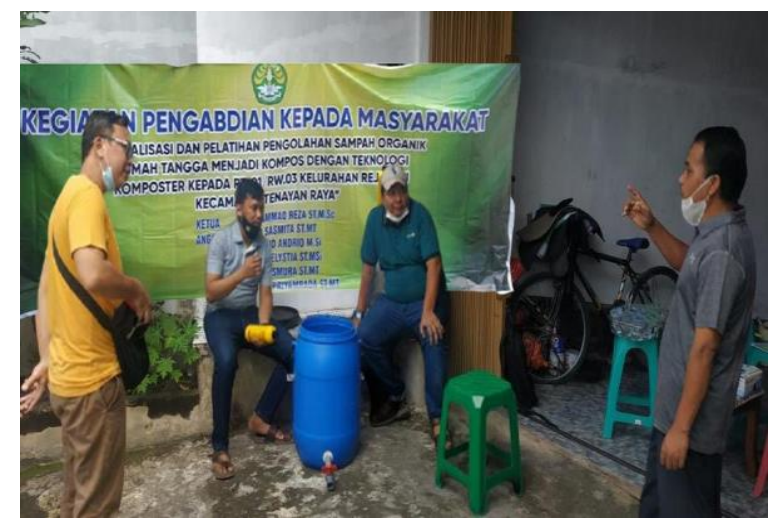

Gambar 3. Sesi Tanya Jawab dan Diskusi dengan Peserta Pengabdian

Pertanyaan-pertanyan yang disampaikan dalam pelatihan membuktikan adanya perhatian terhadap pelatihan yang sedang berlangsung serta harapan mereka untuk bisa mempraktikkannya sendiri, karena alat sangat praktis dan mudah dalam pengolahannya serta mudah dalam membuat alatnya. Kesadaran masyarakat akan pengolahan sampah organik yang ada di lingkungan sekitar mereka menjadi kompos semakin meningkat. Selain itu, telah terjadi peningkatan penerapan Iptek masyarakat sasaran. Di akhir sesi pemberian unit komposter, EM4, dan Modul Teknologi Lingkungan Tepat Guna Pengolahan Sampah menjadi Kompos.
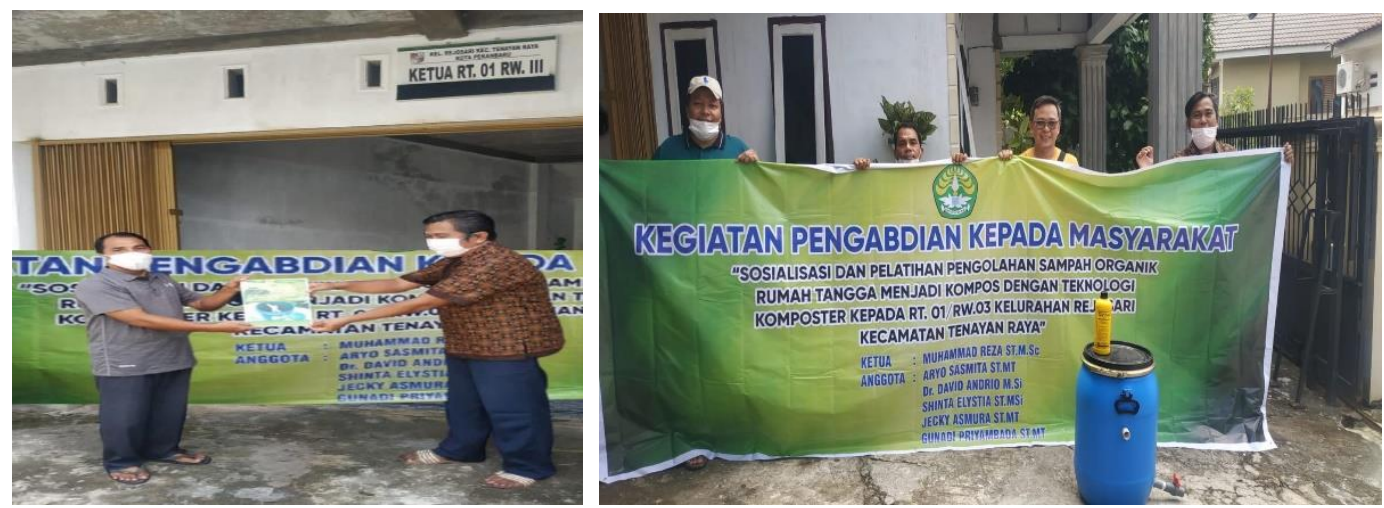

Gambar 4. Penyerahan Modul TLTG Pembuatan Kompos, Komposter Sampah dan EM 4 kepada Ketua RT 01 RW 03

\section{KESIMPULAN}

Kesimpulan mengenai kegiatan pengabdian masyarakat di RT 01 RW 03 Desa Rejosari sebagai berikut: Pelatihan pengelolaan sampah rumah tangga dengan metode komposting di lokasi pengabdian dapat meningkatkan pengetahuan, setidaknya dari tidak tahu menjadi tahu serta berhasil memberdayakanwarga untuk mengolah sampah organik menjadi kompos dengan teknologi komposter. Peningkatan pemahaman bagi peserta pelatihan dilakukan dengan metode ceramah dan demonstrasi serta pemberian kesempatan untuk tanya jawab. Kegiatan pengabdian ini diharapkan ke depan dapat sampai membuka akses pasar bagi hasil produksi. Program 
pengabdian ini diharapkan dapat dilanjutkan pada tahun-tahun berikutnya di lokasi yang lain untuk menunjang kelestarian lingkungan, disamping dapat membantu meningkatkan perekonomian keluarga.

\section{DAFTAR PUSTAKA}

Damanhuri, E. (2010). Diktat Pengelolaan Sampah. Teknik Lingkungan Institut Teknologi Bandung (ITB). Bandung

Djuarnani, N., Kristian, and Setiawan, B.S. (2001). Cara cepat membuat kompos, Agromedia

Faatih, M. (2012). Dinamika Komunitas Aktinobakteria Selama Proses Pengomposan. Jurnal Kesehatan, 15(3), 611-618

Sulistyorini, L. (2005). Pengelolaan Sampah dengan Cara Menjadikannya Kompos. Jurnal Kesehatan Lingkungan, 2(1), 77-84

Suryati, T. (2008). Cara bijak mengolah sampah menjadi kompos dan pupuk cair, Agromedi.

Tchobanoglous, G. and Kreith, F. (2002). Handbook of Solid Waste Management. McGraw-Hill. New York. 